\title{
INVESTMENT OPPORTUNITY SET, DIVIDEND POLICY AND CORPORATE VALUE: EVIDENCE FROM TRADE, SERVICES AND INVESTMENT SECTOR OF INDONESIA STOCK EXCHANGE
}

\author{
Jaka Nugraha \\ Universitas Negeri Surabaya \\ jakanugraha@unesa.ac.id
}

Jurnal Nusantara

Aplikasi Manajemen Bisnis

http://ojs.unpkediri.ac.id/index. $\mathrm{php} / \mathrm{manajemen/index}$

E-ISSN : 2528-0929

P-ISSN : 2549 - 5291

Diterima: 16 Februari 2018

Revisi : 16 Maret 2018

Disetujui: 18 April 2018

https://DOI

10.29407/nusamba.v4i2.12763

\begin{abstract}
The purpose of this paper is to investigate influences the proxy of investment opportunity set and dividend policy on corporate

value. This study is tested with a sample of trade, services and investment sector in Indonesia Stock Exchange which is contained 72 companies covering a 3-years period from 2009 to 2011. Structural equation modeling with Partial Least Square is used in this study. This paper found a significantly positive influence between the proxies of investment opportunity set on dividend policy. In addition, there is a significantly positive influence between the proxies of dividend policy on corporate value. The result had consistently with informational content of dividend that explained that dividend paid was considered to be companies prospect in the future. This result also supported signaling theory that emphasize dividend paid is a signal on the market. The result also revealed a significantly positive influence between the proxies of investment opportunity set on corporate value. This result has supporting and consistently with research result by Fama (1978). Direct effect from investment decision on corporate value is results obtained of investment activity itself.
\end{abstract}




\section{INTRODUCTION}

The major goal of a company is to increase the corporate value in term of the stock price. Stock price is used as a proxy of corporate value, and it makes investor must pay to have it. Financial decisions have an important role in order to the continuity of company. To shareholders, long term investment goal becomes an interesting issue to be observed. Company must consider every strategic decision related to business activities because it will influence stock price and shareholders welfare. Therefore, management must be able to maintain resources effectively and efficiently for improving corporate value. When the company is in a good performance, management will tend to choose new investment than pay a high dividend. The fund which should be paid as cash dividend to shareholders will be used to purchase profitable investment, even to overcome underinvestment problem. Contrarily, the company in slowing growth tends to pay higher dividend for overcoming overinvestment problems. According to Jensen and Meckling (1976), managers tend to invest free cash flow into the investment opportunities and enlarge the company, although it is not profitable.

The growing companies would be responded positively by the market (Vogt, 1997). According to Smith and Watts (1992), the opportunity of company' s growth could be seen on investment opportunities as a proxy of the various combinations of investment opportunities set value (IOS). The growing companies are prospected by investors because the capital invested will provide high return accordance with their expectation. Myers (1977) stated that IOS could be used to predict future condition of the company. According to him, IOS gave extensive guidance where the corporate value as the main direction depended on the company' $\mathrm{s}$ expenditure in the future.

Various literatures assert that corporate value might be influenced by companies' ability to pay dividend. Payment of dividend indicates that management's belief of the future income which will be acquired, so it can be said that payment of dividend was a positive signal or good news. This signal will be responded positively by investors. Thus, it will influence on corporate value, so investors will give high assessment to company which has paid dividend. Nowadays, dividend policy is one of topic in finance which is still in debates. Bhattacharyya (1997) stated that dividend policy was one of the difficult things and it was a challenge for finance economists. A study relating to dividend policy had much been done over the past few decades, but it is still not completely understood the factors affected by dividend policy and how these factors influence each other.

Several theories of dividend policy and its relationship with corporate value recently is still interesting to discuss. Dividend irrelevance theory by Miller and Modigliani (1961) explained that dividend policy was irrelevant, because it had no effect on corporate value or cost of capital. Corporate value depends on investment policy rather than profit which will be distributed for dividend and retained. Further, this theory asserts that corporate value determined by earnings power from company's assets which generate profit and also explain that the profit allocation as dividend does not effect on the corporate value. Bird in hand theory of Gordon and Lintner states the opposite. According to this theory investor prefers company which pays dividend because it lessens

*Corresponding author: jakanugraha@unesa.ac.id 
risk rather than capital gain. The theory expressed by Litzenberger and Ramaswamy is known as tax preference theory said that dividend which shareholders received would be imposed higher tax rather than tax on capital gain. Investor prefers profit acquired by company finally is used for investment which will generate capital gain in the future.

Researches on dividend policy and corporate value have been widely performed. Travlos et al. (2001) proved that dividend was relevant on corporate value and revealed that payments of dividend reduced asymmetry information between management and investor. Corporate value is important concept for investor, because corporate value is market indicator that describe how the market asses overall corporate value. It is caused in corporate value calculation exist of several factor that doesn' $t$ include on calculation of company market capitalization.

Stock markets will reflect the corporate value through the share prices. Optimization of corporate value is the companies' direction which can be achieved through the implementation of financial management function, where a financial decision taken will affect other financial decisions and has an impact on the corporate value (Fama and French, 1998). Shareholders welfare will expand along with increasing the company's share price. Improvement can be achieved if the company is able to give a greater return on investment than capital costs invested. Therefore, the management must be able to manage the resources owned effectively and efficiently. Finally, it can improve the corporate value.

This research was inspired by market crash on the middle of 2008 which affected market sentiment. Whereas company condition showing good performance. This study has been conducted in 2009 till 2011 because Jakarta Composite Index (JCI) has increasing level dramatically at that time. The average year gain during 2005-2011 is $32.17 \%$. In 2005, JCI level is 1162.64 and then became 3821.99 in the end of 2011. This fact showed that index increase $229 \%$ on that period and the record along market was established. Description of JCI movement in 2005-2011 as follows.

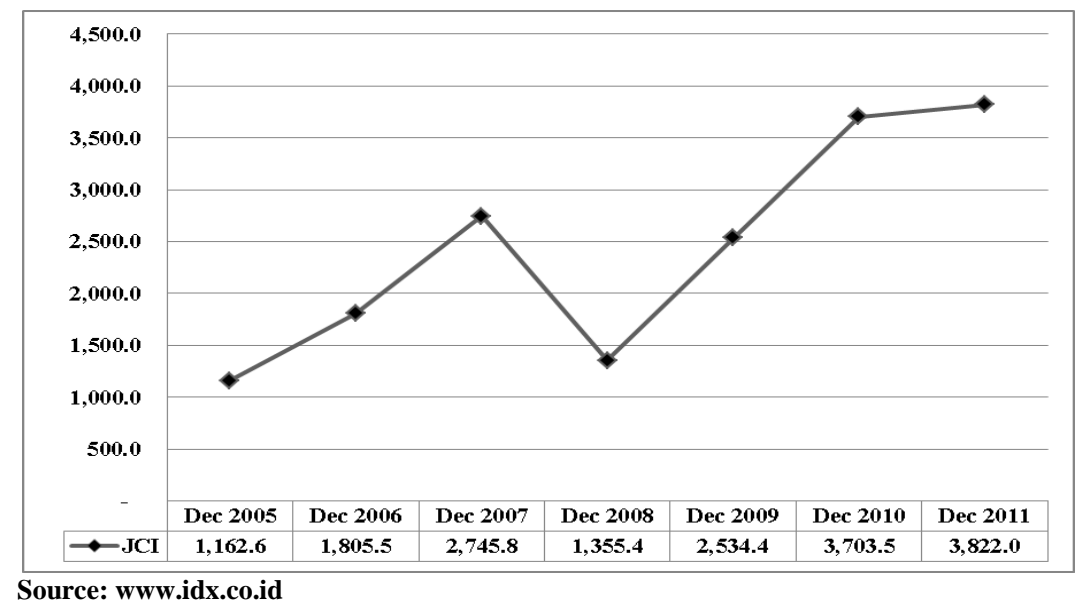

Figure 1. Historical of Jakarta Composite Index Trend 
Manurung (2002) classifying Indonesia Stock Exchange (ISE) as emerging market. The reason which supporting ISE as attractive market is continued rise in JCI level. International Monetary Fund (2012) was announced which is Indonesia as one of emerging market with good economy prospect in the future. The rising numbers of company and expanding market capitalization are proving that ISE was developed every year . Figure 2 presenting those market capitalizations improve from USD 55 Billion became USD 390 Billion. The number of listing company and greater market capitalization every year showed that the economy was growing up.

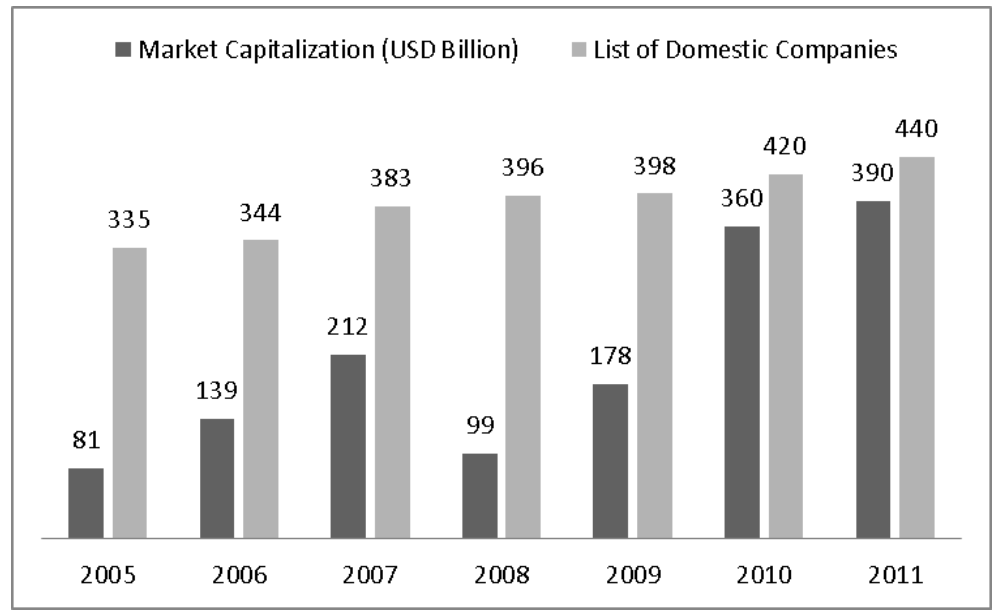

Figure 2. Indonesia Stock Exchange Trend

Table 1. Indonesia Gross Domestic Product year 2009 - 2011

\begin{tabular}{clccc}
\hline No & Sector & $\mathbf{2 0 0 9}$ & $\mathbf{2 0 1 0}$ & $\mathbf{2 0 1 1}$ \\
\hline 1 & Agriculture, livestock, forestry and fishery & 295.9 & 304.7 & 313.7 \\
2 & Mining & 180.2 & 186.6 & 189.2 \\
3 & Industry & 570.1 & 597.1 & 634.2 \\
4 & Electricity & 17.1 & 18.1 & 18.9 \\
5 & Construction & 140.3 & 150 & 160.1 \\
6 & Trading, hotel and restaurant & 368.5 & 400.5 & 437.2 \\
7 & Transportation and communication & 192.2 & 218 & 241.3 \\
8 & Finance, real estate and company services & 209.2 & 221 & 236.1 \\
9 & Services & 205.4 & 217.8 & 232.5 \\
\hline & Gross Domestic Product & $2,178.90$ & $2,313.80$ & $2,463.20$ \\
\hline Source: Indonesia Statistic Bureau & & &
\end{tabular}

Based on the table we know that Indonesia gross domestic product had improving every year. Trade, services and investment are the second sector that gives highest contribution to gross domestic product after industry. Its means that trade, services and sector have prospect to growing and became one of the opportunities to invest every business project on that sector. Although a numerous studies have conducted in the area of investment opportunity set, dividend policy and corporate value. But, the studies on emerging market particularly on trade, services and investment sector is almost absent. Based on the background that already explained before researcher interesting to

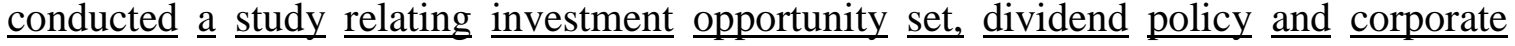




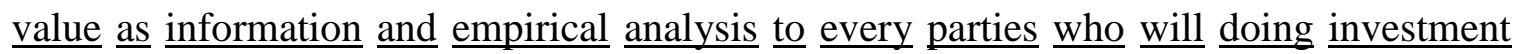
decision or conducted research.

\section{RESEARCH METHOD}

Data used in this study was based on annual report in 2009 until 2011, journal and other publication containing information which is relevant to the topic. Sources of research data are obtained through secondary data. Several data that used are obtained from Indonesia Stock Exchange (www.idx.co.id). The samples are all companies listing on Indonesia Stock Exchange particularly trade, service and investment sector. Table 3.1 showed the criteria mentioned above are acquired 24 unit analysis and total samples for three years 72 sample data. The sample criteria used in this research are as follows:

a) The Companies announcing their financial report per December 31, 2009-2011, it is done to avoid influence of partial time in measuring variables.

b) Companies which paid dividend cash consistently in 2009-2011.

\begin{tabular}{|c|c|c|}
\hline Steps & Procedures & $\begin{array}{c}\text { Year } \\
2009-2011 \\
\end{array}$ \\
\hline 1 & $\begin{array}{l}\text { Companies listed } \\
\text { on Indonesia } \\
\text { Stock Exchange }\end{array}$ & 450 \\
\hline 2 & $\begin{array}{l}\text { Delete companies } \\
\text { not announcing } \\
\text { their financial } \\
\text { report }\end{array}$ & (14) \\
\hline 3 & $\begin{array}{l}\text { Delete companies } \\
\text { have not } \\
\text { distributing } \\
\text { dividend } \\
\text { consistently }\end{array}$ & (339) \\
\hline 4 & $\begin{array}{l}\text { Delete banking, } \\
\text { financial } \\
\text { institution and } \\
\text { insurance }\end{array}$ & (73) \\
\hline \multicolumn{2}{|c|}{ Number of unit analysis } & 24 \\
\hline
\end{tabular}

The variables used in this research are exogenous variable or independent variable, namely, investment opportunity set and endogenous variables or dependent variables, namely, dividend policy and corporate value. Operational definition has defined on Table 3.

\section{Model Specification and Hypothesis}

Technique of data analysis in this research is Structural Equation Modeling (SEM) analysis. SEM is a statistical procedure used to describe the relationship among multiple variables simultaneously (Hair et al., 1995). SEM is relatively less used, especially in 
finance field. The considerations as foundation of using SEM statistics procedures are: 1) providing the method which handles directly multiple relationships simultaneously with providing statistical efficiency, and 2) SEM investigates dependent relationship among various variables or constructs simultaneously. It gives advantage significantly, particularly when dependent variable changes into independent variable in simultaneous equation.

Partial Least Square (PLS) will be used as method of analysis in this research. The main reason using PLS method is variable that used including latent variable which is cannot measure directly and only through indicator to measure. PLS is an alternative method in structural equation model. PLS has been chosen based on research consideration, namely, this research has three latent variables which established with formative indicator (not reflective). This study assumes that indicators are not correlated, so internal consistency reliability measurement (cronbach alpha) not required as reliability test on formative construct (Ghozali, 2006). Basically, formative construct is regression analysis from indicator to construct thus coefficient of regression and coefficient significance are using to assess it. When all the indicator weights are significant, there is empirical support to keep all the indicators. 
Table 3 Operational Definition

\begin{tabular}{|c|c|c|}
\hline Variables & Indicators & Formulas \\
\hline \multirow[t]{5}{*}{$\begin{array}{l}\text { Investment } \\
\text { Opportunity Set / } \\
\text { IOS (X) }\end{array}$} & $\begin{array}{l}\text { 1. Market to book value of asset / } \\
\text { MVABVA }\left(X_{1}\right)\end{array}$ & $\begin{array}{l}\text { 1. Total Asset-Total Equity+(Number of } \\
\text { outstanding share x closing share } \\
\text { prices) / Total Asset }\end{array}$ \\
\hline & $\begin{array}{l}\text { 2. Market to book value of equity } \\
\text { / MVEBVE }\left(\mathrm{X}_{2}\right)\end{array}$ & $\begin{array}{l}\text { 2. (Number of outstanding share } x \\
\text { closing share prices) / Total Equity }\end{array}$ \\
\hline & $\begin{array}{l}\text { 3. Capital expenditure to market } \\
\text { value of assets ratio / } \\
\text { CAPMVA }\left(\mathbf{X}_{3}\right)\end{array}$ & $\begin{array}{l}\text { 3. Book value of fixed asset } t \text { - Book } \\
\text { value of fixed asset } t-1 \text { / Total Asset }- \\
\text { Total Equity }+(\text { Number of } \\
\text { outstanding share x closing share } \\
\text { prices) }\end{array}$ \\
\hline & $\begin{array}{l}\text { 4. Firm value to book value of } \\
\text { property, plant and equipment } \\
\text { / VPPE }\left(\mathbf{X}_{4}\right)\end{array}$ & $\begin{array}{l}\text { 4. Total Asset-Total Equity+(Number of } \\
\text { outstanding share x closing share } \\
\text { prices) / Net fixed asset }\end{array}$ \\
\hline & & $\begin{array}{l}\text { Kallapur and Trombley (1999), Kallapur } \\
\text { and Trombley (2001) }\end{array}$ \\
\hline \multirow[t]{4}{*}{ Dividend policy $\left(\mathbf{Y}_{1}\right)$} & $\begin{array}{l}\text { 1. Dividend Payout Ratio }\left(\mathbf{Y}_{1.1}\right) \\
\text { 2. Dividend yield }\left(\mathbf{Y}_{1.2}\right)\end{array}$ & $\begin{array}{l}\text { 1. Dividend per share / Earnings per } \\
\text { share }\end{array}$ \\
\hline & & $\begin{array}{l}\text { 2. Dividend per share / Closing prices of } \\
\text { common stock }\end{array}$ \\
\hline & 3. Dividend Per Share ( $\left.\mathbf{Y}_{1.3}\right)$ & Subramaniam, (2011) \\
\hline & & $\begin{array}{l}\text { 3. Dividend / Number of outstanding } \\
\text { share }\end{array}$ \\
\hline \multirow[t]{5}{*}{$\begin{array}{l}\text { Corporate value } \\
\left(\mathbf{Y}_{2}\right)\end{array}$} & $\operatorname{1.PBV}\left(Y_{2.1}\right)$ & $\begin{array}{l}\text { 1. Closing prices of common stock / } \\
\text { Equity per share }\end{array}$ \\
\hline & & Fama (1978) \\
\hline & 2.Stock price $\left(\mathbf{Y}_{2.2}\right)$ & 2. Annual closing price \\
\hline & 3. Price Earning Ratio $\left(\mathbf{Y}_{2.3}\right)$ & $\begin{array}{l}\text { 3. Market price per share / Earning per } \\
\text { share }\end{array}$ \\
\hline & & Iturriaga and Sanz (2001) \\
\hline
\end{tabular}

PLS-SEM is the preferred method when the research objective is theory development and prediction (Hair et al, 2011). PLS analysis has steps as follows.

a. Outer model test

Formative indicator is used as dependent variable (endogenous variable) and independent variable (exogenous variable). This study assumes that indicators are not correlated, so internal consistency reliability measurement (cronbach alpha) not required as reliability test on formative construct (Ghozali, 2006). This is different with reflective indicator which using criteria, they are, convergent validity, composite reliability and discriminant validity. Basically, formative construct is regression analysis from indicator to construct thus coefficient of regression and coefficient significance are using to assess it. When all the indicator weights are significant, there is empirical support to keep all the indicators. If both the weight and loading are non-significant, there is no empirical support to retain the indicator and its theoretical relevance should be questioned (Hair et al, 2011).

b. Inner model test

Inner model testing or structural model is used to know relationship among construct, significance value and R2 from research model. Structural model will be evaluated using $\mathrm{R} 2$ for dependent construct (endogenous variable) and t-test and also significance of path 
coefficient on structural model. $\mathrm{R}^{2}$ values of $0.75,0.50$, or 0.25 for endogenous latent variables in the structural model can be described as substantial, moderate, or weak, respectively (Hair et al, 2011). In addition, PLS model also will be evaluated with using Q2 or predictive relevance for constructive model. Q2 will measure observation value based on result in the model and also it parameter estimation.

Meanwhile, accepted and rejected hypothesis criteria as follows.

a. Assess significance value and outer weight each indicators. Weight value which suggested are positive and t-statistic greater 1.645 (p-value < 0.10); 1.960 (p-value < 0.05 ); and 2.576 ( $\mathrm{p}$-value $<0.01$ ) for two tailed. Indicator which has value less than this requirement should be dropped out from model and then re-analysis.

b. Assess inner weight from relationship on latent variable. Weight value should be showed positive with t-statistic greater 1.645 ( $\mathrm{p}$-value < 0.10); 1.960 ( $\mathrm{p}$-value < 0.05); and 2.576 (p-value <0.01) for two tailed.

c. Alternative hypothesis (Ha) has accepted if weight value from relationship on each latent variable showing positive value with t-statistic greater 1.645 ( $\mathrm{p}$-value $<0.10$ ); 1.960 (p-value < 0.05); and 2.576 (p-value < 0.01) for two tailed. Contrarily, H0 failed to rejected if weight value from relationship on each latent variable showing negative value with t-statistic greater 1.645 (p-value < 0.10); 1.960 (p-value < 0.05); and 2.576 (p-value <0.01) for two tailed.

\section{HYPOTHESIS}

\section{Investment Opportunity set and Dividend Policy}

Smith and watts (1992) explained that company with great investment opportunity would prefer applying a policy of lower dividend paid ratio to optimize the internal fund utilization. Further, research held by Gul and Kealey (1999), which took South Korea companies as the sample found the appropriating of the argument of contracting cost which had negative relation between IOS with funding and dividend policy. The same results also implied from research of Abor and Bokpin (2010) and Subramaniam et al. (2011). According to them, there was negative relation between IOS and dividend policy. The hypothesis is:

\section{$H_{1}$ : The proxy of IOS has negative influence on dividend policy}

\section{Dividend Policy and Corporate Value}

Increasing dividend payment will be viewed as signal that company has a good prospect. In Contrast, decreasing dividend payment will be viewed as signal that company has a bad prospect. Dividend policy has significant influence on corporate value. Gordon (1962) as in Brigham and Gapenski (1996) regarding bird in the hand theory stated that shareholder preferred a high dividend payment. It causing having higher certainty than capital gain, and then the hypothesis is:

\section{$\mathrm{H}_{2}$ : The proxy of dividend policy has positive influence on corporate value}

\section{Investment Opportunity set and Corporate Value}

Myers (1977) introduced IOS related with the purpose of companies. According to him, IOS gives direct guidance where the corporate value as the main purpose depends on companies' expenditure in the future. Kallapur and Trombley (2001) revealed that the 
company investment opportunity was an important component from its market value. This was caused by the IOS of a firm was an important characteristic and had great influence on the way how the firm was viewed by managers, owners, investors and creditors. Then the hypothesis is:

$\mathrm{H}_{3}$ : The proxy of IOS has positive influence on corporate value.

\section{RESULTS}

\section{Measurement Model (Outer Model Test)}

Table 5 shows the weights of formative indicators in their respective constructs. These results can be examined to identify the relevance of these indicators for the research model in general and for each formative construct, in particular.

\section{Table 4 Weights of Formative Indicators}

\begin{tabular}{|c|c|c|c|c|c|c|}
\hline Variable & $\begin{array}{c}\text { Original } \\
\text { Sample (O) }\end{array}$ & $\begin{array}{c}\text { Sample } \\
\text { Mean (M) }\end{array}$ & $\begin{array}{l}\text { Standard } \\
\text { Deviation }\end{array}$ & $\begin{array}{l}\text { Standard } \\
\text { Error } \\
\text { (STERR) }\end{array}$ & $\begin{array}{r}\text { T St: } \\
(\mid \mathbf{O} / \mathbf{S}]\end{array}$ & $\begin{array}{l}\text { tistic } \\
\text { ERR) }\end{array}$ \\
\hline \multicolumn{7}{|c|}{$\begin{array}{l}\text { Investment Opportunity Set } \\
\end{array}$} \\
\hline $\mathrm{X} 1$ (MVABVA) & 0.0767 & 0.1032 & 0.2897 & 0.2897 & & 0.2649 \\
\hline X2 (MVEBVE) & 0.5793 & 0.5944 & 0.1762 & \multicolumn{3}{|c|}{$0.17623 .2877 *$} \\
\hline X3 (CAPMVA) & 0.6875 & 0.4797 & 1.1453 & 1.1453 & & 0.6003 \\
\hline X4 (VPPE) & -0.1988 & -0.2133 & 0.0988 & 0.0988 & & 2.0117 \\
\hline \multicolumn{7}{|l|}{ Dividend Policy } \\
\hline Y1.1 (DPR) & -0.0756 & -0.0814 & 0.2689 & 0.2689 & & 0.2810 \\
\hline Y1.2 (Div Yield) & -14.5655 & -14.3984 & 4.4597 & 4.4597 & & 3.2661 \\
\hline Y1.3 (DPS) & 0.7438 & 0.7250 & 0.1591 & \multicolumn{3}{|c|}{$0.15914 .6759^{*}$} \\
\hline \multicolumn{7}{|l|}{ Corporate Value } \\
\hline Y2.1 (PBV) & 0.8977 & 0.8650 & 0.1948 & \multicolumn{3}{|c|}{$0.19484 .6086^{*}$} \\
\hline Y2.2 (Stock Price) & 0.3157 & 0.3443 & 0.1261 & \multirow{2}{*}{\multicolumn{3}{|c|}{$\begin{aligned} 0.12612 .5028^{*} \\
0118041\end{aligned}$}} \\
\hline Y2.3 (PER) & -0.004258 & -0.017738 & 0.118041 & & & .036069 \\
\hline
\end{tabular}

Assess significance value and outer weight each indicators. Weight value which suggested are positive and t-statistic greater 1.645 (p-value < 0.10); 1.960 (p-value < 0.05 ); and 2.576 ( $\mathrm{p}$-value $<0.01$ ) for two tailed. Indicator which has value less than this requirement should be dropped out from model and then re-analysis. T-table value which decided in this study is 1.960 with significance level 0.05 (two-tailed). Further, it will used as cut-off value to accepting or rejecting hypothesis.

Table 6 showed MVEBVE had path coefficient 0.5832 and t-statistic greater 1.96 with significant level is 6.9817 ( $\mathrm{p}$-value $<0.05$ ). This indicated that indicator has been valid and significant in measuring variable investment opportunity set variable. DPS had path coefficient $0.7262 \mathrm{t}$-statistic greater 1.96 with significant level 11.9998 (p-value < 0.05). This is indicated that indicator has been valid and significant in measuring dividend policy variable. PBV and stock price had path coefficient 0.9728 and 0.2575 and t-statistic greater 1.96 with significant level 7.9067 and 4.1281, respectively (p-value $<0.05)$. This is indicated that indicators have been valid and significant in measuring corporate value variable. 
Table 5. Weights of Formative Indicators after deleting not valid indicators

\begin{tabular}{lccrcr}
\hline \multicolumn{1}{c}{ Variable } & $\begin{array}{c}\text { Original } \\
\text { Sample (O) }\end{array}$ & $\begin{array}{c}\text { Sample } \\
\text { Mean (M) }\end{array}$ & $\begin{array}{c}\text { Standard } \\
\text { Deviation }\end{array}$ & $\begin{array}{c}\text { Standard Error } \\
\text { (STERR) }\end{array}$ & $\begin{array}{c}\text { T Statistic } \\
(\mid \text { O/STERR) }\end{array}$ \\
\hline $\begin{array}{l}\text { Investment Opportunity Set } \\
\begin{array}{l}\text { X1 (MVEBVE) } \\
\text { Dividend Policy }\end{array}\end{array}$ & 0.5832 & 0.6069 & 0.0835 & 0.0835 & 6.9817 \\
$\begin{array}{l}\text { Y1.3 (DPS) } \\
\text { Corporate Value }\end{array}$ & 0.7262 & 0.7455 & 0.0605 & 0.0605 & 11.9998 \\
Y2.1 (PBV) & & & & & \\
Y2.2 (Stock Price) & 0.9728 & 0.9627 & 0.1230 & 0.1230 & 7.9067 \\
& 0.2576 & 0.2729 & 0.0624 & 0.0624 & 4.1281 \\
\hline
\end{tabular}

\section{Structural Model (Inner Model Test)}

Inner model testing (structural model) was used to make hypothesis testing in the research. This research had three part of hypothesis testing which have relationship with structural model. Testing had conducted with t-test as in regression analysis. The results from hypothesis testing are as follows:

Table 6. Hypothesis testing of Inner Model

\begin{tabular}{lcccccc}
\hline & $\begin{array}{c}\text { Original } \\
\text { Sample (O) }\end{array}$ & $\begin{array}{c}\text { Sample } \\
\text { Mean (M) }\end{array}$ & $\begin{array}{c}\text { Standard } \\
\text { Deviation }\end{array}$ & $\begin{array}{c}\text { Standard Error } \\
(\text { STERR) }\end{array}$ & $\begin{array}{c}\text { T Statistics } \\
(\text { (O/STERR })\end{array}$ & Statement \\
\hline DP -> CV & 0.159 & 0.159 & 0.064 & 0.064 & 2.483 & Significant \\
IOS -> CV & 0.859 & 0.867 & 0.048 & 0.048 & 17.797 & Significant \\
IOS -> DP & 0.297 & 0.295 & 0.113 & 0.113 & 2.630 & Significant \\
\hline
\end{tabular}

\section{Figure 3. Path Diagram}

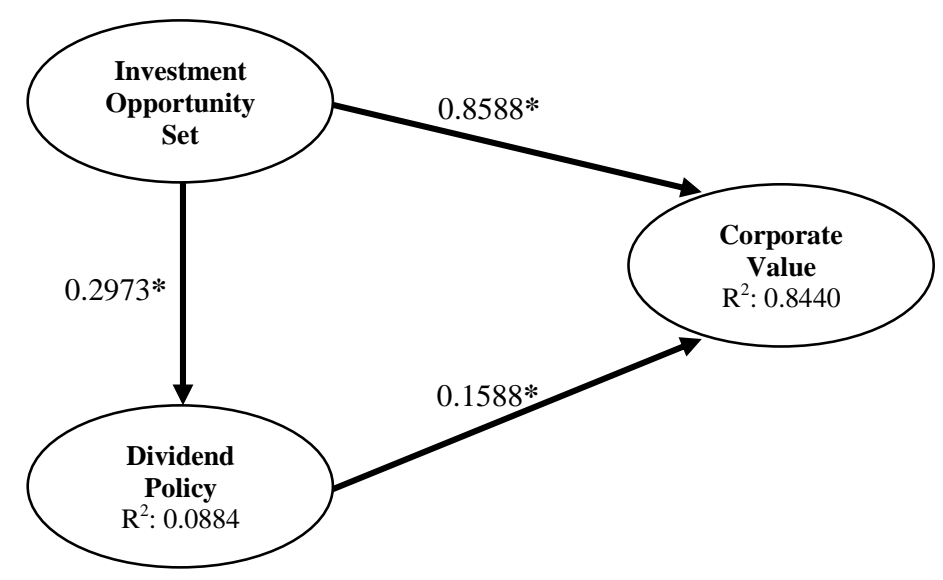

Table 6 and Figure 3 showed the result of hypothesis testing from this research. Then the explanations are as follows.

1. The result revealed a statistically significant positive influence between the proxies of investment opportunity set on dividend policy. Based on PLS analysis has been known that path coefficient 0.2973 and t-statistic 2.6295 are greater 1.96 ( $\mathrm{p}$-value < 0.05). Positive path coefficient revealed that greater of MVEBVE requires raise of DPS (as dividend policy indicator).

2. The proxies of dividend policy on corporate value have a significantly positive influence. Based on PLS analysis has been known that path coefficient 0.1588 and t-statistic 2.4832 are greater 1.96 (pvalue $<0.05)$. Positive path coefficients assert that greater of DPS will increase PBV and stock price (as corporate value indicator).

3. The result also revealed significantly positive influence between the proxies of investment opportunity set on corporate value. Based on PLS analysis shows that path coefficient 0.8588 and t- 
statistic 17.7965 are greater 1.96 ( $\mathrm{p}$-value < 0.05). Positive path coefficient reveals that greater of MVEBVE will increase PBV and stock price.

Goodness and fit structural model in PLS analysis is value of predictive relevance $\left(Q^{2}\right)$. Those value calculated based on $\mathrm{R}^{2}$ from endogenous variables, they were:

1. Dividend policy variable obtained $\mathrm{R}^{2} 0.0884$.

2. Corporate value variable obtained $\mathrm{R}^{2} 0.8440$.

Predictive relevance formula as follows:

$\mathrm{Q}^{2}=1-\left(1-\mathrm{R} 1^{2}\right)\left(1-\mathrm{R} 2^{2}\right)$

$\mathrm{Q}^{2}=1-(1-0.0884)(1-0.8440)$

$\mathrm{Q}^{2}=1-(0.9116)(0.1560)$

$\mathrm{Q}^{2}=1-0.1422$

$\mathrm{Q}^{2}=0.8577$

Predictive relevance value is 0.8577 or $85.77 \%$. This indicated that the diversity of data can be explained on model is $85.77 \%$, or in other word, information which contained on the data is $85.77 \%$ and can be explained by model. While remaining $14.22 \%$ explained by another variable (which is not contained in the model) and error. Thus, this result can be used to hypothesis testing.

\section{DISCUSSION}

The research result has been obtained significantly positive influence between the proxy of IOS on dividend policy. PLS analysis showed path coefficient is 0.2973 and t-statistic is 2.6295 , greater 1.96 (p-value < 0.05). This indicated that company with higher level of MVEBVE will attempt to increase the number of nominal share that will be paid to shareholder as optimistic on profit obtained in the future. Positive path coefficient revealed that the higher company's growth based on their asset to operate their companies requires higher DPS (as dividend policy indicator). The results of this study have not support previous empirical studies that have been conducted by Smith and Watts (1992), Gaver and Gaver (1993) Gul and Kelaey (1999), Abor and Bokpin (2010), Subramaniam et al. (2011) which found that there is negative significant relationship between IOS and dividend policy. Based on this result explained that companies investment opportunities improvement through the power of equity, and then effect on increasing their dividend policy. It will be happened because in the future companies optimistic to earn higher profit through new project investment. Thus, companies will ensure the shareholder with increasing the number of dividend.

The second hypothesis result has been obtained significantly positive influence between the proxy of dividend policy on corporate value. PLS analysis showed path coefficient is 0.1588 and t-statistic is 2.4832, greater 1.96 ( $\mathrm{p}$-value $<0.05$ ). This indicated that dividend policy (DPS as indicator of dividend policy) will affect corporate value. Positive path coefficient showed that there was positive influence between the proxy of dividend policy and corporate value. The greater dividend that will be paid to shareholder has impact on increasing of corporate value. Basically, if companies increasing dividend will be seen by investor as signal that companies will be growing in the future to earn profit and maximize shareholder value. The result had consistently with informational content of dividend that explained that dividend paid was considered to be companies prospect in the future. This result also supported signalling theory that emphasize dividend paid is a signal on the market and describes companies growth and prospect in the future, thus dividend payment will improve market appreciation on companies stock, thereby dividend payment gives positive implication on the corporate value. In addition, this result generally support existing literature and research on dividend policy and corporate value as Gordon (1963), Bhattacharya (1979), Myers and Majluf (1984), and Nishat and Irfan (2003) 
and Hussainey et al. (2011) which reveals that there are significant positive relationship between dividend and corporate value.

The third hypothesis result has been obtained significantly positive influence between the proxy of IOS on corporate value. PLS analysis showed path coefficient is 0.8588 and t-statistic is 17.7965 is greater 1.96 (p-value < 0.05). Positive path coefficient presented that there was positive influence between IOS and corporate value. It means that the increasing of IOS will effect on improving companies corporate value. Significantly result means that company with high level of MVEBVE will overview on investor if company has prospect in the future to earn higher profit. The conclusion based on maximum of corporate value assumption will be obtained through selecting investment which gives positive net present value. It means, those investments have been considered and analysis through the chosen method. Thereby, investment expenditure will give positive signal regarding company growth in the future, then increasing stock price. The result presents that investment decision has influence on corporate value. This result has supporting and consistently with research result by Fama (1978). Direct effect from investment decision on corporate value is results obtained of investment activity itself through selecting project or another policy as create new product, machine replacement, improvement of research and development and merger (Myers, 1977). In addition, deciding investment decision, public company will able to control business risk that they face. Implication from conclusion is that corporate value has been established through market value of stock strongly influenced by investment opportunities and discretionary expenditure in the future (Myers, 1977; Myeong dan Hyeon, 1998). This result also supports signalling theory. Capital expenditure has important role in order to improve corporate value. Because, this investment will give signal related companies growth and expected return in the future and also will increasing market value with stock return as proxy (Fama dan French, 1998). The result generally support existing literature and research on IOS and corporate value as research by Myeong and Hyeon (1998), Belkaoui and Picur (2001) which found significant positive relationship between IOS and corporate value.

\section{CONCLUSIONS}

This paper used structural equation modelling to examine the relationship among investment opportunity set, dividend policy and corporate value on listing companies of trade, service and investment sector in Indonesia Stock Exchange using Partial Least Square. The study concluded that there is statistically significant positive influence between the proxy of investment opportunity set and dividend policy. In addition the proxy of dividend policy has a significantly positive influence on corporate value. The result also revealed a significantly positive influence between proxies of investment opportunity set on corporate value. Limitation of this research is that we used relative a short period of time of 3 years. This period could be developed longer so will obtain greater sample and diversity. It will effect on result within estimating influence of research variable.

Future research is suggested to include some other variables which have influence on corporate value as macro economy, capital structure or financing decision or even different indicator in the same variable. Additional variable will give comprehensive description and result concerning investment opportunity set, dividend policy and corporate value. Those variables have linkages with company condition, prospect, growth, and corporate value.

\section{References}

Abor, Joshua. and Godfred A Bokpin. (2010). Investment Opportunities, Corporate Finance, and Dividend Payout Policy: Evidence from Emerging Markets. The Journal of Economics and Finance, 27 (3): 180-194.

Al-Malkawi, H.N. (2007). Determinants of Corporate Dividend Policy in Jordan: An Application of the Tobit Model. The Journal of Applied Accounting Research, 23: 44-70. 
Al-Najjar, B. and K Hussainey. (2009). The Association Between Dividend Payout and Outside Directorships. The Journal of Applied Accounting Research, 10: 4-19.

Battacharya, S. (1979). Imperfect Information \& Dividend Policy and The 'Bird in Hand' Fallacy. The Bell Journal of Economics, 10: 259-70.

Battacharya, S. (1997). Dividend Policy: A review. The Journal of Managerial Finance, 1: 4-13.

Belkaoui, Ahmed R. and Ronald D Picur. (2001). Investment Opportunity Set Dependence of

Dividend Yield and Price Earnings Ratio. The Journal of Managerial Finance, 27 (3): 65-71.

Black, F. (1976). The Dividend Puzzle. The Journal of Portfolio Management, 2: 5-8.

Brigham, Eugene F., and M.C Ehrhardt. (2005). Financial Management Theory and Practice, 11th

DeAngelo, H., L DeAngelo. and D.J Skinner. (1996). Reversal of Fortune: Dividend Policy and the

Disappearance of Sustained Earnings Growth. The Journal of Financial Economics, 40 (3): 341-71.

Easterbrook, F.H. (1984). Two Agency-Cost Explanations of Dividends". The American Economic Review , 74: 650-9.

Elloum, Fathi. and J.P. Gueyie. (2001). CEO Compensation, IOS and the Role of Corporate

Governance". The Journal of Corporate Governance, 1 (2): 23-34.

Fama, Eugene.F. (1978). The Effects of Firm's Investment and Financing Decisions on the Welfare

of Its Security Holders. The American Economic Review, 68 (3): 272-284.

Fama, Eugene F. and Kenneth R French. (1998). Taxes, Financing Decisions, and Firm Value. The Journal of Finance, 53 (3): 819-843.

Fama, E. and K French. (2001). Disappearing Dividends: Changing Firm Characteristics or Lower Propensity to Pay?. The Journal of Financial Economics , 60: 3-43.

Gaver, Jennifer.J. and Kenneth.M Gaver. (1995). Compensation Policy and The Investment Opportunity Set". The Journal of Financial Management, 24 (1): 19-32.

Ghozali, Imam. (2006). Structural Equation Modeling: Metode Alternatif dengan partial Least

Square. Badan Penerbit UNDIP. Semarang.

Gul F.A. and B.T Kealey. (1999). Chaebol, Investment Opportunity Set and Corporate Debt

and Dividend Policies of Korean Companies. Rev. Quant. Finance and Accounting, 13: 401-416.

Hayes, T. (2001). The Research Driven Investor How to use Information Data and Analysis for Investment Success. McGraw Hill. New York. p 305.

Hair, J.F., W.J Black., B.J. Babin, R.F Anderson. and R.L. Tatham. (1995). Multivariate Data Analysis, 6th Edition. Pearson International Edition.

Hair, J.F., C.M. Ringle and M. Sarstedt. (2011). PLS-SEM: Indeed a Silver Bullet. The Journal of Marketing Theory and Practice, 19 (2): 139-151.

Hussainey, Khaled., Chijoke Oscar Mgbame. and Aruoriwo M. C Mgbame. (2011). Dividend

Policy and Share Price Volatility: UK Evidence. The Journal of isk Finance, 12 (1):57-68.

International Monetary Fund, World Economic Outlook Update. 2012.

Indonesian Capital Market Directory, Annual Report, Indonesia Stock Exchange 2009.

Indonesian Capital Market Directory, Annual Report, Indonesia Stock Exchange 2010.

Indonesian Capital Market Directory, Annual Report, Indonesia Stock Exchange 2011

Itturiaga, Felix J. Lopes and Juan Antonio Rodrigues Sanz. (2001). Ownership Structure, Corporate

Value and Firm Investment: A Simultaneous Equations Analysis of Spanish Companies. The Journal of Management and Governance, 5 (2): 179-204.

Jensen, M.C. and William.H Meckling. 1976. "Theory of the Firm: Managerial Behavior, Agency Cost and Ownership Structure". The Journal of Financial Economics, 3 (4): 305-360.

Kallapur, S., and M. Trombley. 1999. "The Association Between Investment Opportunity Set Proxies and Realized Growth". The Journal of Business Finance and Accounting, 26 (3\&4): 505-519.

Kallapur, Sanjay. and M.A Trombley. 2001. "The Investment Opportunity Set: Determinants, Consquences, and Measurement". The Journal of Managerial Finance, 27 (3): 3-15.

Lintner, J. 1956. "The Distribution of Incomes of Corporations among Dividends, Retained Earnings and Taxes". American Economic Review, 46: 97-113. 
Miller, M.H. and F Modigliani. 1961. "Dividend Policy, Growth and the Valuation of Shares". The Journal of Business , 34: 411-33.

Myeong-Heon Cho. 1998. "Ownership Structure, Investment, and the Corporate Value: An Empirical Analysis". The Journal of Financial Economics, 47: 103-121.

Myers, S. 1977. "Determinants of Corporate Borrowing". The Journal of Financial Economics, pp.147-175.

Myers, Stewart.C. and N.S Majluf. 1984. "Corporate Financing and Investment Decisions When Firms Have Information That Investors Do Not Have". The Journal of Financial Economics, 13:187221.

Myers, S. 1977. "Determinants of Corporate Borrowing". The Journal of Financial Economics, 5:147-175.

Nishat, Mohammed and C.M. Irfan. 2003. "Dividend Policy and Stock Price Volatility in Pakistan. Finance, Economic, and Accounting Conference, pp. 1-22.

Ross, Stephen. A. (1977). The Determination of Financial Structure: The Incentive - Signaling Approach. The Bell Journal of Economics, 8 (1): 23-40.

Rozeff, M. (1982). Growth Beta and Agency Cost as Determinants of Dividend Payout Ratios. The Journal of Financial Research, pp. 249-259.

Smith, C.W., Jr. and R.L Watts. (1992). The Investment Opportunity Set and Corporate Financing, Dividends, and Compensation Policies. The Journal of Financial Economics, 32: 262-292.

Subramaniam, R., S.S. Devi, and M Marimuthu. (2011). Investmment Opportunity Set and Dividend Policy in Malaysia. The Journal of Business Management, 5 (24): 10128-10143.

Vogt, Stephen C. (1997). Cash Flow and Capital Spending: Evidence from Capital Expenditure Announcements. The Journal of Financial Management, 26 (2): 44-57. 